\title{
Uji Efek Analgetika Ekstrak Etanol Buah Ceplukan (Physalis angulata L.) pada Mencit Putih Jantan
}

\author{
Indriani ${ }^{1}$ \\ ${ }^{1}$ Bagian Farmakologi Fakultas Kedokteran Universitas Al Khairaat Palu
}

Email: Sidney_1484@yahoo.co.id

\begin{abstract}
One of the medicinal plants used in traditional medicine is ceplukan (Physalis angulata L.). This research was animal at observing the effect of analgetic potency of analgetic activity and comparison with acetaminophen. The research used wringgle method with acetic acid as pain stimulant of tested animal for 60 minutes. The animal test is the white male mouse strain for DDI, 8-12 weeks old and with the weight between 20-30 gram, as such as 50 mice devided into 5 treatment groups. Group I was as the negative control given aquadest, group II was the positive control given acetaminophen with the dose of $65 \mathrm{mg} / \mathrm{kg}$ weight, group III,IV and V were given the extractum fruit's of ceplukan's ethanol (Physalis angulata L.) with the dose of $0,03 \mathrm{~g} / \mathrm{kg}$ weight; $0,1 \mathrm{~g} / \mathrm{kg}$ weight; $0,3 \mathrm{~g} / \mathrm{kg}$ weight is given orally. And it was respectively, the tested animal was allowed the sette to 5 minutes then injected with acetic acid $0,5 \%$ with the dose $50 \mathrm{mg} / \mathrm{kg}$ weight by intraperitonealy. Respons were observed every 5 minutes during one hour and calculated with the Hendersoth and Forsaith method. The data among group were analized by one way variant (ANOVA) and followed by t-test method in $95 \%$ degree of significant. The result of this research has indicated that the dose of the extractum fruit's of ceplukan's ethanol (Physalis angulata L.) has the analgetic effect. Each group of treatment III, IV and IV came out $22,20 \% ; 47,84 \%$ and $77,98 \%$ gave the analgetic effect. For extractum fruit's of ceplukan's (Physalis angulata L.) with the dose $0,03 \mathrm{~g} / \mathrm{kg}$ weight $(22,20 \%)$ and $0,1 \mathrm{~g} / \mathrm{kg}$ weight $(47,98 \%)$ less than acetaminophen $(66,42 \%)$, and extractum fruit's of ceplukan's ethanol (Physalis angulata L.) with the dose $0,3 \mathrm{~g} / \mathrm{kg}$ weight has the bigger level of analgetic than acetaminophen $(66,42 \%)$.
\end{abstract}

Keywords: ceplukan fruit, analgetic effect, Physalis angulata L.

\section{Abstrak}

Salah satu tumbuhan obat yang digunakan dalam pengobatan tradisional adalah ceplukan (Physalis angulata L.). Penelitian ini bertujuan untuk mengetahui efek analgetik dan seberapa besar daya analgetik ekstrak etanol buah ceplukan dibanding parasetamol. Penelitian ini menggunakan metode geliat dengan rangsangan kimia asam asetat dari hewan uji selama 60 menit. Hewan uji yang digunakan adalah mencit putih jantan galur DDI, yang berumur 812 minggu, dengan berat badan 20-30 gram sebanyak 50 ekor yang dibagi menjadi 5 kelompok perlakuan. Kelompok I sebagai kontrol negatif diberi aquadest, kelompok II sebagai kontrol positif diberi parasetamol dosis $65 \mathrm{mg} / \mathrm{kg} \mathrm{BB}$, kelompok III, IV dan V diberi ekstrak etanol buah ceplukan (Physalis angulata L.) dengan dosis 0,03 g/kg BB; 0,1 $\mathrm{g} / \mathrm{kg}$ BB dan $0,3 \mathrm{~g} / \mathrm{kg}$ BB secara peroral. Setelah diberi perlakuan, hewan uji didiamkan selama 5 menit, setelah itu disuntik dengan asam asetat $0,5 \% \mathrm{v} / \mathrm{v}$ dosis $50 \mathrm{mg} / \mathrm{kg}$ BB secara intraperitoneal sebagai rangsang nyeri. Kemudian diamati jumlah kumulatif geliat tiap 5 menit selama 1 jam. Daya analgetika dihitung dengan menggunakan persamaan Hendersoth and Forsaith. Data yang diperoleh kemudian dianalisis statistik menggunakan analisis varian satu jalan (ANAVA) dan dilanjutkan dengan uji-t taraf kepercayaan $95 \%$. Hasil penelitian menunjukkan bahwa ekstrak etanol buah ceplukan (Physalis angulata L.) mempunyai efek analgetika. Daya analgetika tiap kelompok perlakuan ekstrak etanol buah ceplukan (Physalis angulata L.) berturut-turut adalah kelompok III, IV dan V sebesar 22,20\%; 47,84\% dan 77,98\%. Efek analgetika ekstrak etanol buah ceplukan (Physalis angulata L.) dosis $0,03 \mathrm{~g} / \mathrm{kg}$ BB (22,20\%) dan ekstrak etanol buah ceplukan (Physalis angulata L.) dosis $0,1 \mathrm{~g} / \mathrm{kg} \mathrm{BB}(47,84 \%)$ lebih kecil daripada parasetamol (66,42\%). Ekstrak etanol buah ceplukan (Physalis angulata L.) dosis 0,3 g/kg BB (77,98\%) mempunyai efek analgetika yang lebih besar daripada parasetamol $(66,42 \%)$.

Kata Kunci : Buah ceplukan, efek analgetik, Physalis angulata L. 


\section{PENDAHULUAN}

Pemerintah telah menetapkan kebijaksanaan dalam upaya pelayanan kesehatan yaitu Primary Health Care (PHC) sebagai suatu strategi untuk mencapai kesehatan masyarakat pada tahun 2006. salah satu unsur penting dalam PHC antara lain penerapan teknologi tepat guna dan peran serta masyarakat.

Upaya pengobatan tradisional dengan obat-obat tradisional merupakan salah satu bentuk peran serta masyarakat dan sekaligus merupakan teknologi tepat guna yang potensial untuk menunjang pembangunan kesehatan. Hal ini disebabkan antara lain karena pengobatan tradisional sejak dulu kala dimanfaatkan oleh masyarakat serta bahanbahannya banyak terdapat diseluruh pelosok tanah air $^{1}$.

Salah satu tumbuhan obat yang digunakan dalam pengobatan tradisional adalah ceplukan (Physalis angulata L.). Kegunaan tumbuhan ceplukan antara lain adalah untuk menghilangkan panas (antipiretika), menghilangkan rasa nyeri (analgetika), peluruh air seni (diuretika), menetralkan racun (detoxifie) dan meredakan batuk $(\text { cough sedative })^{2}$.

Salah satu kandungan kimia pada buah ceplukan adalah flavonoid. Buah ceplukan dapat dibuat dalam bentuk sediaan infusa dan ekstrak etanol, karena flavonoid dapat larut di dalamnya. Hal ini juga diperkuat oleh uji efek analgetik infusa buah ceplukan dengan kadar $40 \% \mathrm{~b} / \mathrm{v}$, dosis $10 \mathrm{~g} / \mathrm{kg} \mathrm{BB}$ mempunyai efek analgetik ${ }^{3}$. Penelitian ini dimaksudkan untuk membuktikan secara ilmiah apakah ekstrak etanol buah ceplukan dapat digunakan sebagai obat analgetika.

\section{METODE PENELITIAN}

Penelitian yang dilakukan adalah penelitian eksperimental dengan rancangan acak lengkap.yaitu percobaaan yang bertujuan untuk mengetahui suatu gejala atau pengaruh yang timbul akibat dari adanya perlakuan tertentu. Penelitian dilakukan untuk mengetahui potensi dan besaran daya analgetik ekstrak etanol buah ceplukan dengan beberapa tingkatan dosis yang telah ditentukan pada hewan uji yang dalam keadaan sehat.

Sampel dan teknik sampling sampel yang digunakan adalah buah ceplukan yang diambil di daerah Gayam, Gondokusuman, Baciro pada bulan Januari 2005. Teknik sampling yang di gunakan adalah Purposive Sampling yaitu pengambilan sampel secara sengaja sesuai dengan pertimbangan tertentu dari peneliti.

Hewan uji yang digunakan adalah mencit putih jantan galur DDI, dengan berat antara 20-30 gram dan umur yang digunakan adalah 8-12 minggu diperoleh dari Laboratorium Penelitian dan Pengujian Terpadu (LPPT), Universitas Gadjah 
Mada, Yogyakarta. Selain itu dipilih mencit yang kondisinya sehat, dipelihara secara baku. Pengelompokan hewan uji dilakukan secara acak dan dibuat 5 kelompok yang tiap kelompoknya terdiri dari 10 ekor mencit.

Bahan kimia yang digunakan adalah parasetamol (PT. Phapros) yang diperoleh dari Apotek Hayam Wuruk, asam asetat glacial pro analisis dan aquadest yang diperoleh dari Laboratorium Farmakologi Fakultas Farmasi Gadjah Mada, Yogyakarta.

Alat-alat yang digunakan dalam penelitian ini adalah jarum suntik, jarum oral, corong Buchner, rotary evaporator, penangas air listrik, kertas saring, kain flanel, alat-alat gelas, timbangan mencit, neraca analitik Sartorius Bp 160 P, Stopwatch, blender dan almari pengering.

\section{Determinasi tumbuhan}

Determinasi tumbuhan dilakukan di laboratorium Biologi Fakultas FMIPA Universitas Ahmad

Dahlan. Determinasi ini dilakukan untuk menyakinkan bahwa tanaman yang diteliti adalah buah ceplukan (Physalis angulata L ). Determinasi tanaman dilakukan dengan berpedoman buku Flora Untuk Sekolah Di Indonesia.

\section{Pembuatan simplisia buah ceplukan}

Buah ceplukan yang sudah dicabut lalu dibersihkan, dan dicuci kemudian dipotong-potong, dikeringkan di bawah sinar matahari tak langsung dengan ditutup kain hitam sampai buah ceplukan kering, kemudian diserbuk dengan menggunakan blender, ditimbang sesuai kadar yang dikehendaki.

\section{Pembuatan ekstrak kering buah ceplukan}

Simplisia yang telah diserbuk sebanyak 120 gram ditambahkan pelarut etanol $70 \% \mathrm{~b} / \mathrm{v}$ sebanyak 750 ml sampai semua terendam, diperoleh ekstrak kering 22,5 g. Setelah itu dilakukan pengadukan dengan menggunakan pengaduk stirrer selama 2 jam. Rendaman tersebut disimpan di tempat terlindung dari cahaya langsung dan diaduk kembali. Menurut persyaratan bahwa rendaman harus diaduk kira-kira tiga kali sehari, kemudian dimaserasi selama 5 hari. Setelah itu rendaman disaring dengan kertas saring dengan corong Buchner yang dibantu Vacuum. Cairan maserasi dan cairan yang diperoleh melalui penyaringan disatukan, selanjutnya diatur sampai mencapai kadar dan jumlah yang diinginkan dengan cairan hasil pencucian sisa penyaringan menggunakan bahan ekstraksi (Voight,1984). Untuk memperoleh ekstrak pekat tanpa adanya etanol yaitu dengan melakukan evaporasi menggunakan alat rotary evaporator pada suhu $90^{\circ} \mathrm{C}$.

\section{Penetapan susut pengeringan}

Ekstrak kental yang diperoleh ditentukan susut pengeringan dengan cara seperti yang tertera dalam Farmakope Indonesia III. Sebanyak 1 gram ekstrak ditimbangan dalam cawan petri yang sebelumnya 
telah dipanaskan pada suhu $105^{\circ} \mathrm{C}$ selama \pm 30 menit dan telah ditara. Setelah itu dimasukkan kedalam almari pengering, hingga bobotnya tetap. Botol dikeluarkan dari almari pengering, dimasukkan kedalam eksikator, di dinginkan, ditimbang beratnya dan dimasukkan lagi didalam almari pengering. Pengeringan ini dilakukan sampai didapat berat yang konstan. Dalam penelitian ini susut pengeringan dilakukan pada suhu $50^{\circ} \mathrm{C}$ dengan interval waktu tiap 5 menit.

\section{Penentuan dosis}

Dosis Parasetamol

Diketahui dosis lazim parasetamol $500 \mathrm{mg}$ sekali minum untuk manusia dengan berat badan rata-rata $70 \mathrm{~kg}$, Faktor konversi manusia ke mencit. berat 20 g adalah 0,0026 maka dosis parasetamol untuk mencit $=0,0026 \times 500 \mathrm{mg}=1,3 \mathrm{mg} / 20$ gram $\mathrm{BB}=$ $65 \mathrm{mg} / \mathrm{kg}$. Selanjutnya dibuat stok larutan parasetamol dengan kadar $1 \% \mathrm{~b} / \mathrm{v}$ atau 1 gram/100 ml. Telah dilakukan orientasi terhadap larutan parasetamol dengan kadar $0,3 \% \mathrm{~b} / \mathrm{v}$ dan $1 \% \mathrm{~b} / \mathrm{v}$ diperoleh $\%$ proteksi parasetamol kadar $0,3 \% \mathrm{~b} / \mathrm{v}$ lebih kecil dari pada \% proteksi parasetamol kadar $1 \% \mathrm{~b} / \mathrm{v}$. sehingga dalam penelitian ini menggunakan parasetamol dengan kadar $1 \% \mathrm{~b} / \mathrm{v}$.

Dosis asam asetat

Penentuan dosis asam asetat dilakukan langsung pada dosis $50 \mathrm{mg} / \mathrm{kg} \mathrm{BB}$, asam asetat $0,5 \% \mathrm{v} / \mathrm{v}$ diberikan secara i.p. dengan mengacu pada penelitian sebelumnya yang menyatakan bahwa dosis yang cukup baik adalah $50 \mathrm{mg} / \mathrm{kg} \mathrm{BB}^{4}$.

Dosis ekstrak kering etanol buah ceplukan.

Dosis tersebut dalam bentuk gram/ BB, telah dilarutkan dengan aquadest dengan interval 3 dan 3 + $\log 3$ menjadi kadar $0,04 \%$ b/v ; 0,12\% b/v ; $0,4 \% \mathrm{~b} / \mathrm{v}$ dan $1,2 \% \mathrm{~b} / \mathrm{v}$ untuk orientasi, masingmasing kadar dihitung dengan mengacu pada 0,5 $\mathrm{ml} / 20 \mathrm{~g} \mathrm{mencit}^{5}$. Sedangkan pada penelitian ini hanya menggunakan 3 macam kadar yaitu $0,12 \%$ $\mathrm{b} / \mathrm{v} ; 0,4 \% \mathrm{~b} / \mathrm{v}$ dan $1,2 \% \mathrm{~b} / \mathrm{v}$

Hewan uji dibagi kelompok dengan masingmasing kelompok terdiri dari 10 ekor.

Kelompok I : sebagai kontrol negatif diberi aquadest

Kelompok II : sebagai pembanding, diberi suspensi parasetamol dalam CMC $\mathrm{Na}$ dosis $65 \mathrm{mg} / \mathrm{kg}$ $\mathrm{BB}$

Kelompok III : diberi ekstrak etanol buah ceplukan dosis $\quad 0,03 \mathrm{~g}$ serbuk/kg BB

Kelompok IV : diberi ekstrak etanol buah ceplukan $0,1 \mathrm{~g}$ serbuk/kg BB

Kelompok V : diberi ekstrak etanol buah ceplukan $0,3 \mathrm{~g}$ serbuk/kg BB 
Masing-masing kelompok diberi perlakuan dosis tunggal per oral. Selang 5 menit kemudian diberi asam asetat $0,5 \% \mathrm{v} / \mathrm{v}$ sebagai penyebab nyeri dengan dosis $50 \mathrm{mg} / \mathrm{kg} \mathrm{BB}$ secara intra peritoneal. Lalu diamati geliatnya, hal ini ditandai dengan kaki belakang ditarik ke belakang dan perut mengempis. Waktu pengamatan dilakukan selama 60 menit, dengan mencatat jumlah kumulatif geliatnya kemudian diolah dengan diuji statistik menggunakan metode analisis varian 1 jalan dilanjutkan uji Tukey dengan taraf kepercayaan 95\% untuk mengetahui apakah ada perbedaan yang bermakna antara kelompok uji dan kelompok kontrol.

\section{HASIL DAN PEMBAHASAN}

\section{Determinasi}

Rangkuman hasil determinasi adalah sebagai berikut :

$1 b, 2 b, 3 b, 4 b, 6 b, 7 b, 9 b, 10 b, 11 b, 12 b, 13 b, 14 a$, 15a, (golongan 8) 109b, 119b,k 120b, 128b, 129b, 135b, 136b, 139b, $140 \mathrm{~b}, 142 \mathrm{~b}, 143 \mathrm{~b}, 146 \mathrm{~b}, 154 \mathrm{~b}, 155 \mathrm{~b}, 156 \mathrm{~b}, 162 \mathrm{~b}$, 163b, 167b, 169b, 171b, 177b, 179b, 187b, 189b, 190b, 191a (Fam 111 Solanaceae)

1b, 3b, 5a (3, Physalis) - 1a (Physalis angulata L.) (Steenis, 1981)

\section{Hasil pengujian daya analgetika}

Metode pengujian daya analgetika yang digunakan dalam penelitian ini adalah Siegmund dengan rangsang kimia asam asetat $0,5 \%$ v/v sebagai penyebab rasa nyeri. Untuk mengetahui apakah ekstrak etanol buah ceplukan mempunyai efek analgetika yang berupa penghambatan mediator nyeri dapat dilihat dalam bentuk geliat. Geliat ini merupakan suatu tanda bahwa hewan uji mengalami nyeri akibat perlakuan pemberian asam asetat yaitu ditandai dengan tarikan kaki kebelakang dan perut mengempis. Selain itu untuk mengetahui seberapa besar daya analgetika ekstrak etanol buah ceplukan jika dibandingkan dengan parasetamol. 
Tabel 1. Jumlah Kumulatif Geliat Mencit Selama 60 Menit

\begin{tabular}{|c|c|c|c|c|c|}
\hline \multirow{2}{*}{$\begin{array}{l}\text { No. } \\
\text { Mencit }\end{array}$} & \multicolumn{5}{|c|}{ Jumlah kumulatif geliat } \\
\hline & I & II & III & IV & V \\
\hline 1 & 78 & 42 & 81 & 46 & 24 \\
\hline 2 & 74 & 45 & 75 & 58 & 20 \\
\hline 3 & 81 & 32 & 78 & 52 & 16 \\
\hline 4 & 84 & 40 & 91 & 51 & 8 \\
\hline 5 & 93 & 36 & 82 & 46 & 19 \\
\hline 6 & 110 & 41 & 97 & 55 & 34 \\
\hline 7 & 123 & 37 & 69 & 54 & 22 \\
\hline 8 & 135 & 42 & 83 & 66 & 28 \\
\hline 9 & 142 & 24 & 92 & 71 & 37 \\
\hline 10 & 152 & 21 & 86 & 63 & 28 \\
\hline$\Sigma$ & 1072 & 360 & 834 & 562 & 236 \\
\hline $\mathbf{X}$ & 107,2 & 36,0 & 83,4 & 56,2 & 23,6 \\
\hline SD & $\pm 29,12$ & $\pm 8,028$ & $\pm 8,422$ & $\pm 8,324$ & $\pm 8,591$ \\
\hline $\mathrm{CV}$ & $27,16 \%$ & $22,29 \%$ & $10,09 \%$ & $14,58 \%$ & $36,41 \%$ \\
\hline
\end{tabular}

Keterangan tabel :

Kelompok I : Kontrol negatif ( aquadest)

Kelompok II : Kontrol positif ( parasetamol $65 \mathrm{mg} / \mathrm{kg}$ BB

Kelompok III : Ekstrak etanol buah ceplukan 0,12 \% b/v yang setara dengan dosis 0,03 g/ kg BB.

Kelompok IV : Ekstrak etanol buah ceplukan 0,4 \% b/v yang setara dengan dosis $0,1 \mathrm{~g} / \mathrm{kg}$ BB.

Kelompok V : Ekstrak etanol buah ceplukan 1,2 \% b/v yang setara dengan dosis 0,3 g/ kg BB. 


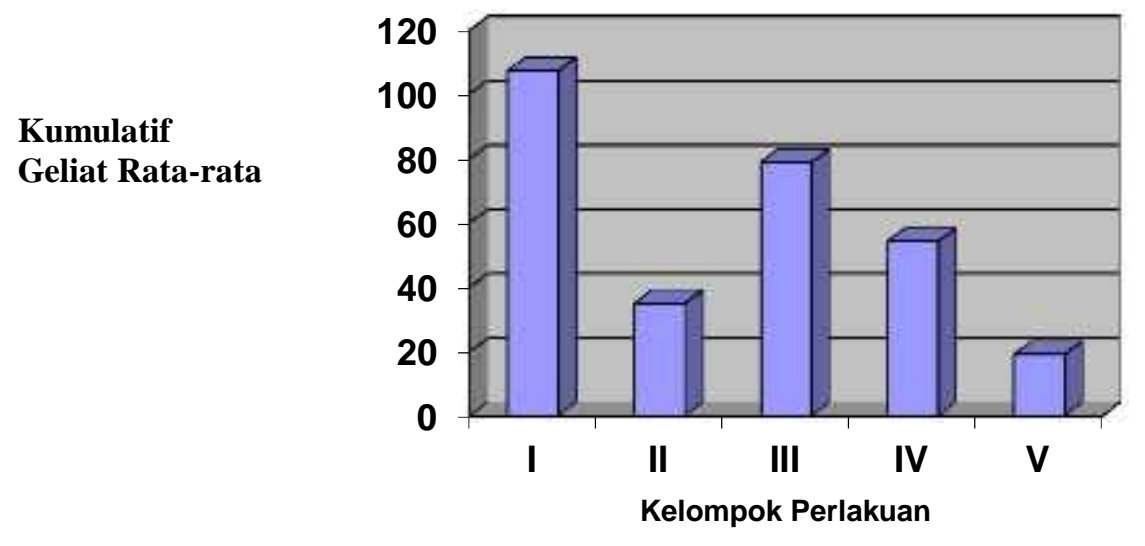

Gambar 1 : Diagram Jumlah Kumulatif Geliat Rata-rata dari kelompok perlakuan

Keterangan gambar :

Kelompok I : Kontrol negatif ( aquadest)

Kelompok II : Kontrol positif ( parasetamol 65 mg/kg BB )

Kelompok III : Ekstrak etanol buah ceplukan 0,12 \% b/v yang setara dengan dosis 0,03 g/ kg BB

Kelompok IV : Ekstrak etanol buah ceplukan $0,4 \%$ b/v yang setara dengan dosis $0,1 \mathrm{~g} / \mathrm{kg} \mathrm{BB}$

Kelompok V : Ekstrak etanol buah Ceplukan $1,2 \%$ b/v yang setara dengan dosis $0,3 \mathrm{~g} / \mathrm{kg} \mathrm{BB}$

Hasil pengamatan yang diperoleh dari metode geliat ini berupa jumlah kumulatif geliat selama 60 menit. Dari tabel 1 dan gambar 1 disajikan jumlah kumulatif geliat mencit dari masing-masing kelompok perlakuan. Kelompok I sebagai kontrol negatif yaitu aquadest ditambah CMC Na 0,5\%. Kelompok II sebagai kelompok pembanding yaitu parasetamol dosis $65 \mathrm{mg} / \mathrm{kg} \mathrm{BB}$. Sedangkan untuk kelompok III, IV, dan V diberi ekstrak etanol buah ceplukan dengan dosis berturut- turut $0,03 \mathrm{~g} / \mathrm{kg}$ $\mathrm{BB}, 0,1 \mathrm{~g} / \mathrm{kg} \mathrm{BB}, 0,3 \mathrm{~g} / \mathrm{kg} \mathrm{BB}$.

Dari tabel maupun gambar tersebut dapat dilihat jumlah kumulatif geliat mencit kelompok I (kontrol negatif ) jauh lebih besar dari kelompok III, IV, V serta pembanding atau kelompok II ( kontrol positif ). Pada kelompok I yaitu kontrol negatif, jumlah kumulatif geliat yang paling banyak karena hanya diberi aquadest ditambah $\mathrm{CMC} \mathrm{Na}$ tidak diberi obat analgetik, sehingga tidak dapat menghambat mediator nyeri akibatnya rasa nyeri yaitu yang diwujudkan sebagai geliat yang paling besar.

Untuk kelompok III, IV, V terjadi penurunan jumlah kumulatif yang berbeda-beda dengan perlakuan parasetamol, ekstrak etanol buah ceplukan dengan kadar $0,12 \% \mathrm{~b} / \mathrm{v}, 0,4 \% \mathrm{~b} / \mathrm{v}, 1,2$ $\%$ b/v, memiliki efek sebagai analgetika yang 
berbeda-beda, dimana semakin sedikit jumlah kumulatif geliatnya maka semakin besar kemampuannya untuk menghambat nyeri. Selanjutnya data jumlah kumulatif geliat tersebut dianalisis dengan menggunakan uji pendahuluan One-sample Kolmogorov-Smirnov untuk memastikan distribusi data penelitian. Dari data tersebut diperoleh signifikansi 0,546 > 0,05 yang berarti data jumlah kumulatif geliat terdistribusi normal.

Dari uji pendahuluan Kolmogorov-Smirnov menunjukkan distribusi yang normal, maka dilanjutkan dengan uji Levene, dan diperoleh signifikan $0,000<0,05$ yang berarti data tersebut tidak homogen sehingga tidak dapat diuji dengan analisis Varian satu jalan (ANAVA) karena tidak memenuhi salah satu syarat asumsi yang diperlukan dalam uji ANAVA. Dengan demikian data jumlah kumulatif geliat dianalisis dengan uji KruskalWallis dengan taraf kepercayaan 95\% untuk mengetahui perbedaan yang bermakna antar kelompok. Hasil analisisnya dapat dilihat pada tabel 2.

Tabel 2. Ringkasan Hasil Uji Kruskal-Wallis dari Data Jumlah Kumulatif Geliat

\begin{tabular}{|c|c|}
\hline \multicolumn{2}{|c|}{ Test Statistics $^{\text {a,b }}$} \\
\hline & Geliat \\
\hline Chi-Square & 45,147 \\
df & 4 \\
Asymp.Sig. &, 000 \\
\hline
\end{tabular}

a. Kruskal-Wallis Test

b. Grouping Variable : JUMLAH KUMULATIF GELIAT

Tabel 2 menunjukkan bahwa harga signifikansi $0,000<0,05$, maka berarti ada perbedaan yang sangat bermakna pada kelompok perlakuan, sehingga untuk mengetahui ada tidaknya perbedaan yang bermakna antar pasangan kelompok perlakuan, dilanjutkan dengan uji Mann-Whitney

Tabel 3. Ringkasan Hasil Uji Mann-Whitney Jumlah Kumulatif Geliat antar Kelompok Perlakuan.

\begin{tabular}{|c|c|c|c|c|c|c|}
\hline \multicolumn{2}{|c|}{} & \multicolumn{5}{|c|}{ KELOMPOK } \\
\cline { 2 - 7 } \multicolumn{2}{c|}{} & I & II & III & IV & V \\
\hline K & I & & & & & \\
E & & & & & & \\
L & II & S & & & & \\
O & & III & TS & S & & \\
M & & S & S & S & & \\
P & IV & S & S & S & S & \\
\hline & K & V & S & S & & \\
\hline
\end{tabular}


Keterangan tabel :
a. Kelompok I : Kontrol negatif (Aquadest)
b. Kelompok II : Kontrol positif ( Parasetamol dosis $65 \mathrm{mg} / \mathrm{kg} \mathrm{BB}$ )
c. Kelompok III : Ekstrak etanol buah ceplukan dosis $0,03 \mathrm{~g} / \mathrm{kg} \mathrm{BB}$
d. Kelompok IV : Ekstrak etanol buah ceplukan dosis $0,1 \mathrm{~g} / \mathrm{kg} \mathrm{BB}$
e. Kelompok V : Ekstrak etanol buah ceplukan dosis $0,3 \mathrm{~g} / \mathrm{kg}$ BB
f. Simbol S : Berbeda Signifikan

Tabel 3 menunjukkan ada perbedaan yang bermakna antar pasangan kelompok perlakuan yaitu kelompok I (Kontrol negatif ), kelompok II ( Kontrol positif ), dan kelompok III, IV, V yang masing-masing diberi ekstrak etanol buah ceplukan kadar 0,03 g/kg BB; 0,1 g/kg BB; 0,3 g/kg BB, menunjukkan adanya perbedaan yang bermakna. Hal ini berarti pada kelompok-kelompok yang diberi ekstrak etanol buah ceplukan memiliki efek sebagai analgetika.

Pada kelompok I (kontrol negatif) dibandingkan dengan kelompok II, IV dan V diperoleh harga P < 0,05. hal ini berarti ada perbedaan jumlah kumulatif geliat yang signifikan antar kelompok kontrol negatif dengan kelompok perlakuan lainnya karena kelompok kontrol negatif tidak diberikan obat analgetika yang dapat menghambat nyeri, sehingga menghasilkan jumlah geliat yang paling banyak.

Pada kelompok II (kontrol positif) yaitu kelompok perlakuan parasetamol dibandingkan dengan kelompok I, III, IV dan V diperoleh harga $\mathrm{P}<0,05$. Hal ini berarti ada perbedaan jumlah kumulatif geliat yang signifikan antara kelompok kontrol positif dengan kelompok perlakuan lain, dimana jumlah kumulatif geliat parasetamol lebih sedikit dari kelompok kontrol negatif, ekstrak etanol buah ceplukan dosis $0,03 \mathrm{~g} / \mathrm{kg} \mathrm{BB}$, dan ekstrak etanol buah ceplukan dosis $0,1 \mathrm{~g} / \mathrm{kg} \mathrm{BB}$, tetapi lebih besar daripada kelompok perlakuan ekstrak etanol buah ceplukan dosis $0,3 \mathrm{~g} / \mathrm{kg}$ BB. Hal ini berarti kelompok II memiliki kemampuan menghambat mediator nyeri.

Pada kelompok III yaitu ekstrak etanol buah ceplukan dosis $0,03 \mathrm{~g} / \mathrm{kg}$ BB dibandingkan dengan kelompok II,IV dan IV diperoleh harga $\mathrm{P}<0,05$. Hal ini berarti ada perbedaan jumlah kumulatif geliat yang signifikan antara kelompok III dengan kelompok perlakuan lainnya, dimana jumlah kumulatif geliat dosis $0 ., 03 \mathrm{~g} / \mathrm{kg}$ BB lebih besar dari kelompok perlakuan parasetamol, ekstrak etanol buah ceplukan dosis $0,1 \mathrm{~g} / \mathrm{kg}$ BB dan ekstrak etanol buah ceplukan dosis $0,3 \mathrm{~g} / \mathrm{kg} \mathrm{BB}$, tetapi lebih sedikit daripada kelompok perlakuan aquadest.

Pada kelompok IV yaitu ekstrak etanol buah ceplukan dosis $0,1 \mathrm{~g} / \mathrm{kg}$ BB dibandingkan dengan kelompok I,II,III dan V diperoleh harga $\mathrm{P}<0,05$. 
hal ini berarti ada perbedaan jumlah kumulatif geliat yang signifikan antara kelompok IV dengan kelompok perlakuan lainnya, dimana jumlah kumulatif geliat ekstrak etanol buah ceplukan dosis $0,1 \mathrm{~g} / \mathrm{kg}$ BB lebih besar dari kelompok perlakuan parasetamol dan ekstrak etanol buah ceplukan dosis $0,3 \mathrm{~g} / \mathrm{kg} \mathrm{BB}$, tetapi lebih sedikit daripada kelompok perlakuan aquadest dan ekstrak etanol buah ceplukan dosis $0,03 \mathrm{~g} / \mathrm{kg} \mathrm{BB}$. Hal ini berarti kelompok IV mempunyai kemampuan menghambat nyeri.

Pada kelompok V yaitu ekstrak etanol buah ceplukan $0,3 \mathrm{~g} / \mathrm{kg} \quad \mathrm{BB}$ dibandingkan dengan kelompok I, II, III dan IV diperoleh harga $\mathrm{P}<0,05$. Hal ini berarti ada perbedaan jumlah kumulatif geliat yang signifikan antara kelompok $\mathrm{V}$ dengan kelompok perlakuan lainnya, dimana jumlah kumulatif geliat dosis $0,3 \mathrm{~g} / \mathrm{kg}$ BB lebih sedikit dari kelompok perlakuan lainnya. Hal ini berarti kelompok $\mathrm{V}$ mempunyai kemampuan menghambat nyeri yang paling baik dari kelompok lainnya. Sedangkan pada kelompok I sebagai kontrol negatif (aquadest) dibandingkan dengan kelompok III yaitu ekstrak etanol buah ceplukan dosis $0,03 \mathrm{~g} / \mathrm{kg}$ BB diperoleh harga $\mathrm{P}>0,05$. hal ini berarti tidak ada perbedaan jumlah kumulatif geliat yang singnifikan artinya tingkat perbedaan uji antar kelompok perlakuan tidak berbeda jauh.

Dari uraian diatas terlihat bahwa besarnya kemampuan tiap kelompok untuk menekan nyeri berbanding terbalik dengan jumlah kumulatif geliatnya. Sehingga dapat disimpulkan bahwa jumlah kumulatif geliat dapat digunakan sebagai parameter analgetika. Berdasarkan hasil uji MannWhitney antara kelompok perlakuan parasetamol, ekstrak etanol buah ceplukan dosis $0,03 \mathrm{~g} / \mathrm{kg} \mathrm{BB}$; $0,1 \mathrm{~g} / \mathrm{kg}$ BB dan $0,3 \mathrm{~g} / \mathrm{kg} \mathrm{BB}$ dengan kelompok kontrol negatif ( aqaudest) menunjukkan adanya perbedaan yang bermakna sehingga ekstrak etanol buah ceplukan dipastikan bisa sebagai analgetika. Selanjutnya dari data jumlah kumulatif geliat mencit masing-masing perlakuan ditentukan persentase penghambatan dengan menggunakan persamaan Hendershot-Forsaith.

Tabel 4. Persen Proteksi Dari Tiap Kelompok Perlakuan

\begin{tabular}{|c|c|c|c|c|}
\hline \multirow{2}{*}{$\begin{array}{c}\text { No } \\
\text { Mencit }\end{array}$} & \multicolumn{4}{|c|}{ Kelompok Perlakuan } \\
\cline { 2 - 5 } & II (\%) & III (\%) & IV(\%) & V (\%) \\
\hline 1 & 60,82 & 24,44 & 57,09 & 77,61 \\
\hline 2 & 58,02 & 30,03 & 45,89 & 81,34 \\
\hline 3 & 70,15 & 27,24 & 51,49 & 85,07 \\
\hline 4 & 62,69 & 15,11 & 52,43 & 92,54 \\
\hline 5 & 66,42 & 23,51 & 57,09 & 82,28 \\
\hline
\end{tabular}




\begin{tabular}{|c|c|c|c|c|}
\hline 6 & 61,75 & 9,52 & 51,31 & 68,28 \\
\hline 7 & 65,48 & 35,63 & 49,63 & 79,48 \\
\hline 8 & 60,82 & 22,57 & 38,43 & 73,88 \\
\hline 9 & 77,61 & 14,18 & 33,78 & 65,48 \\
\hline 10 & 80,41 & 19,78 & 41,23 & 73,88 \\
\hline$\Sigma$ & 664,17 & 222,01 & 478,37 & 779,84 \\
\hline $\mathbf{X}$ & $\mathbf{6 6 , 4 2}$ & $\mathbf{2 2 , 2 0}$ & $\mathbf{4 7 , 8 4}$ & $\mathbf{7 7 , 9 8}$ \\
\hline SD & $\mathbf{\pm 7 , 4 9}$ & $\mathbf{\pm 7 , 8 5}$ & $\mathbf{\pm 7 , 8 5}$ & $\mathbf{+ 8 , 0 2}$ \\
\hline $\mathbf{C V}$ & $\mathbf{1 1 , 2 8 \%}$ & $\mathbf{3 5 , 3 6 \%}$ & $\mathbf{1 6 , 4 1 \%}$ & $\mathbf{1 0 , 2 8 \%}$ \\
\hline
\end{tabular}

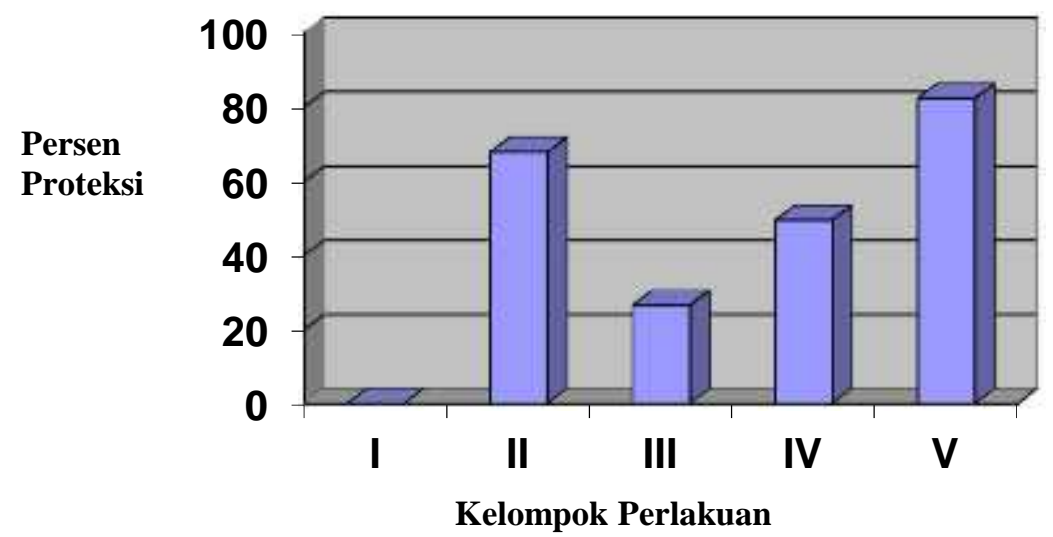

Gambar 2. Diagram Batang Persen Proteksi dari Tiap Kelompok Perlakuan

Keterangan tabel dan gambar :

Kelompok I : Kontrol negatif (aquadest ditambah CMC Na )

Kelompok II : Kontrol positif ( parasetamol $65 \mathrm{mg} / \mathrm{kg} \mathrm{BB}$ )

Kelompok III : Ekstrak etanol buah ceplukan $0,12 \% \mathrm{~b} / \mathrm{v}$ yang setara dengan dosis $0,03 \mathrm{~g} / \mathrm{kg} \mathrm{BB}$

Kelompok IV : Ekstrak etanol buah ceplukan $0,4 \%$ b/v yang setara dengan dosis $0,1 \mathrm{~g} / \mathrm{kg} \mathrm{BB}$

Kelompok V : Ekstrak etanol buah ceplukan 1,2 \% b/v yang setara dengan dosis 0,3 g/ kg BB.

Perbedaan persen proteksi dari semua kelompok perlakuan terlihat pada tabel IV dan gambar 10 . dari data tersebut dapat disimpulkan bahwa peningkatan kadar ekstrak etanol buah ceplukan menyebabkan peningkatan persen proteksi, yaitu berturut-turut kadar $0,12 \% \mathrm{~b} / \mathrm{v} ; 0,4 \% \mathrm{~b} / \mathrm{v} ; 1,2 \% \mathrm{~b} / \mathrm{v}$ mempunyai persen proteksi sebesar 22,20\%; 47,84\%; 77,98\%. Besarnya daya analgetika dari 
masing-masing kelompok tersebut menunjukkan besarnya kemampuan menghambat nyeri. Kelompok I (kontrol negatif) persen proteksinya sama dengan nol, berarti untuk kelompok ini tidak mempunyai kemampuan manghambat nyeri.

Untuk kelompok III dan IV yaitu ekstrak etanol buah ceplukan kadar $0,12 \% \mathrm{~b} / \mathrm{v}$ memiliki persen proteksi sebesar $22,20 \%$ dan ekstrak etanol buah ceplukan kadar $0,4 \% \mathrm{~b} / \mathrm{v}$ memiliki persen proteksi sebesar 47,48\%. Menurut Turner 1965, suatu percobaan dikatakan mempunyai daya analgetika jika persen penghambatannya sama dengan atau lebih besar dari 50\%, sehingga untuk kelompok III dengan kadar $0,12 \% \mathrm{~b} / \mathrm{v}$ dan kelompok IV dengan kadar $0,4 \% \mathrm{~b} / \mathrm{v}$ belum bisa memberikan efek analgetik karena persen penghambatannya belum mencapai $50 \%{ }^{5}$. Sedangkan untuk V yaitu ekstrak etanol buah ceplukan dengan kadar $1,2 \% \mathrm{~b} / \mathrm{v}$ memiliki persen proteksi sebesar $77,98 \%$. Hal ini berarti kelompok $\mathrm{V}$ dapat memberikan efek analgetika karena persentase penghambatannya melebihi $50 \%$.

Tabel 5. Hasil ANAVA dari Persen Proteksi Tiap Kelompok Perlakuan

\begin{tabular}{|c|c|c|c|}
\hline Sumber varian & $\begin{array}{c}\text { Jumlah } \\
\text { Kuadrat (SS) }\end{array}$ & $\begin{array}{c}\text { Derajat } \\
\text { Bebas }(\mathrm{dB})\end{array}$ & $\begin{array}{c}\text { Mean } \\
\text { Kuadrat(MB) }\end{array}$ \\
\hline Perlakuan ( antar kelompok ) & 40460,35 & 4 & 10115,088 \\
\hline Error percobaan ( dalam kelompok ) & 2504,41 & 45 & 55,65 \\
\hline TOTAL & 42964,76 & 49 & 10170,74 \\
\hline $\begin{array}{l}\text { F hitung } \\
\text { F table } 0,05(4,45)\end{array}$ & $\begin{array}{c}181,76 \\
2,61-2,53\end{array}$ & & \\
\hline
\end{tabular}


Dari tabel 5 dapat dilihat bahwa F hitung $(181,76)$ lebih besar dari F tabel $(2,61-2,53)$ yang berarti bahwa ada perbedaan yang signifikan pada kelompok perlakuan. Karena dari hasil ANAVA menunjukkan adanya perbedaan yang signifikan, maka dilakukan ujit dengan taraf kepercayaan $95 \%$, untuk mengetahui ada atau tidaknya perbedaan yang bermakna antar pasangan kelompok perlakuan. Berikut ini akan disajikan hasil analisis uji-t persen proteksi antar kelompok perlakuan dapat dilihat pada tabel VI.

Tabel 6. Hasil Uji-t Persen Proteksi antar Kelompok Perlakuan

\begin{tabular}{|c|l|c|c|}
\hline No. & Perbandingan & Keterangan & $\begin{array}{c}\text { Hasil } \\
\text { persentase } \\
\text { Daya } \\
\text { analgetika }\end{array}$ \\
\hline 1. & K II dan III & Bermakna & II $>$ III \\
2. & K II dan IV & Bermakna & II $>$ IV \\
3. & K II dan V & Bermakna & V > II \\
4. & K III dan IV & Bermakna & IV > III \\
5. & K III dan V & Bermakna & V > III \\
6. & K IV dan V & Bermakna & V > IV \\
\hline
\end{tabular}

Keterangan tabel :

Kelompok II : Kontrol positif ( parasetamol 65 mg/kg BB )

Kelompok III : Ekstrak etanol buah ceplukan 0,12\% $\mathrm{b} / \mathrm{v}$ yang setara dengan dosis $0,03 \mathrm{~g} / \mathrm{kg} \mathrm{BB}$

Kelompok IV : Ekstrak etanol buah ceplukan 0,4 \% $\mathrm{b} / \mathrm{v}$ yang setara dengan dosis $0,1 \mathrm{~g} / \mathrm{kg} \mathrm{BB}$

Kelompok V : Ekstrak etanol buah ceplukan 1,2\% $\mathrm{b} / \mathrm{v}$ yang setara dengan dosis $0,3 \mathrm{~g} / \mathrm{kg} \mathrm{BB}$

- $\quad$ thitung $>\mathrm{t}$ tabel $=$ bermakna

- $\quad \mathrm{t}$ hitung $=\mathrm{t}$ tabel $=$ tidak bermakna
Dari tabel 6 dapat dilihat bahwa ada perbedaan yang bermakna antar pasangan kelompok perlakuan. Parasetamol sebagai kontrol positif dan kelompok III, IV, V masing-masing diberi ekstrak etanol buah ceplukan kadar 0,12 \% b/v, 0,4 \% b/v, 1,2 \% b/v, menunjukkan ada perbedaan yang bermakna. Hal ini berarti ada efek analgetika pada kelompok-kelompok yang diberi ekstrak etanol buah ceplukan. Pada kelompok II yaitu kelompok perlakuan parasetamol dengan kelompok perlakuan lainnya yaitu kelompok III, IV dan V diperoleh harga t hitung jauh lebih besar dari t tabel $(2,101)$, berarti ada perbedaan persen penghambatan yang signifikan antar kelompok perlakuan parasetamol dengan kelompok lainnya. Dimana persen penghambatan kelompok perlakuan parasetamol lebih besar daripada kelompok perlakuan ekstrak etanol buah ceplukan dosis $0,03 \mathrm{~g} / \mathrm{kg} \mathrm{BB}$ dan dosis $0,1 \mathrm{~g} / \mathrm{kg}$ BB tetapi lebih kecil daripada ekstrak etanol buah ceplukan dosis $0,3 \mathrm{~g} / \mathrm{kg} \mathrm{BB}$.

Pada kelompok III yakni ekstrak etanol buah ceplukan dosis $0,03 \mathrm{~g} / \mathrm{kg} \mathrm{BB}$ dibandingkan dengan kelompok II, IV dan V diperoleh harga t hitung yang jauh lebih besar dari t tabel $(2,101)$, yang berarti ada perbedaan persen penghambatan yang signifikan antara kelompok perlakuan lainnya. Hal tersebut dapat dilihat dari persen penghambatan kelompok perlakuan ekstrak etanol buah ceplukan dosis $0,03 \mathrm{~g} / \mathrm{kg}$ BB lebih kecil dari kelompok perlakuan parasetamol, kelompok 
perlakuan ekstrak etanol buah ceplukan dosis $0,1 \mathrm{~g} /$ $\mathrm{kg} \mathrm{BB}$ dan $0,3 \mathrm{~g} / \mathrm{kg} \mathrm{BB}$.

Pada kelompok IV yakni ekstrak etanol buah ceplukan dosis $0,1 \mathrm{~g} / \mathrm{kg}$ BB dengan kelompok II, III dan V juga diperoleh harga t hitung yang jauh lebih besar dari $\mathrm{t}$ tabel $(2,101)$, yang berarti ada perbedaan persen pengambatan yang signifikan antara kelompok perlakuan IV dengan kelompok perlakuan yang lainnya. Persen penghambatan pada kelompok perlakuan ekstrak etanol buah ceplukan dosis $0,1 \mathrm{~g} / \mathrm{kg}$ BB lebih besar dari kelompok perlakuan ekstrak etanol buah ceplukan dosis $0,03 \mathrm{~g} / \mathrm{kg} \mathrm{BB}$, tetapi lebih kecil daripada kelompok perlakuan parasetamol dan kelompok perlakuan ekstrak etanol buah ceplukan dosis $0,3 \mathrm{~g} / \mathrm{kg} \mathrm{BB}$.

Pada kelompok V yakni ekstrak etanol buah ceplukan dosis $0,3 \mathrm{~g} / \mathrm{kg}$ BB dengan kelompok II, III dan IV juga diperoleh harga t hitung yang jauh lebih besar dari $\mathrm{t}$ tabel (2,101), yang berarti ada perbedaan persen penghambatan yang signifikan dengan kelompok perlakuan lainnya dan memiliki kemampuan mengurangi atau menghambat nyeri yang paling baik dari kelompok lainnya.

Dari uraian diatas dapat disimpulkan bahwa jumlah kumulatif geliat dapat digunakan sebagai parameter analgetika, karena semakin sedikitnya jumlah kumulatif geliat menggambarkan semakin besar kemampuan menekan nyeri dan juga dapat diketahui bahwa kelompok perlakuan kontrol negatif tidak mempunyai kemampuan menekan nyeri. Berdasarkan hasil Uji-t antar kelompok perlakuan secara keseluruhan menunjukkan adanya perbedaan yang bermakna antar kelompok perlakuan dengan kelompok kontrol negatif, sehingga ekstrak etanol buah ceplukan mempunyai efek analgetik. Diduga senyawa yang bertanggung jawab dalam menimbulkan efek analgetik dalam buah ceplukan adalah flavonoid ${ }^{6}$. Sedangkan senyawa kimia yang terkandung dalam tanaman ceplukan yang dapat berefek analgetik adalah asam askorbat, beta sitosterol, asam klorogenat, kaemferol, asam linoleat, magnesium, asam oleat, rutin dan thiamin ${ }^{7}$. Berdasarkan kelarutannya, dari senyawa senyawa tersebut yang dapat larut dalam etanol adalah kaemferol dan rutin.

\section{KESIMPULAN}

Hasil penelitian yang diperoleh menunjukkan bahwa ekstrak etanol buah ceplukan (Physalis angulata L.) mempunyai efek analgetik pada mencit putih jantan galur DDI. Dengan semakin meningkatnya dosis ekstrak etanol buah ceplukan (Physalis angulata L.), maka persentase efek analgetiknya semakin meningkat. Persentase efek analgetik ekstrak etanol buah ceplukan dosis $0,03 \mathrm{~g} / \mathrm{kg} \mathrm{BB} ; 0,1 \mathrm{~g} / \mathrm{kg} \mathrm{BB}$; dan $0,3 \mathrm{~g} / \mathrm{kg} \mathrm{BB}$ berturut-turut adalah $22,20 \%$; 47,84\%; dan $77,98 \%$. Daya analgetik kelompok ekstrak etanol buah ceplukan (Physalis angulata L.) dosis $0,003 \mathrm{~g} / \mathrm{kg}$ BB dan 0,1 $\mathrm{g} / \mathrm{kg}$ BB lebih rendah dari parasetamol $65 \mathrm{mg} / \mathrm{kg} \mathrm{BB}$. Sedangkan ekstrak etanol buah ceplukan (Physalis 
angulata L.) dosis $0,3 \mathrm{~g} / \mathrm{kg} \mathrm{BB}$ mempunyai daya analgetik yang lebih besar dari parasetamol. Daya analgetik kelompok ekstrak etanol buah ceplukan dosis 0,3 $\mathrm{g} / \mathrm{kg}$ memiliki persen proteksi sebesar 77,98\% sehingga dapat memberikan efek analgetik karena persen penghambatannya lebih besar dari $50 \%$.

\section{DAFTAR PUSTAKA}

1. Hargono D, Wibisana W. 1995. Pemanfaatan Tanaman Obat untuk Kesehatan Keluarga. Cetakan kedua. Penerbit Depdikbud dan Rineka Cipta. Jakarta

2. Wijayakusuma H. 1994. Tanaman Berkhasiat Obat di Indonesia. Jilid I. Pustaka Kartini, Jakarta

3. Triastuti. 2005. Uji Efek Analgetik Infusa Buah Ceplukan (physalis angulata L.) pada Mencit Putih Jantan. Skripsi. Fakultas Farmasi Universitas Ahmad Dahlan. Jogjakarta

4. Lestari K. 2003. Uji Efek Analgetik Ekstra Etanol Daun Jambu Mete anacardium occidentale L pada Mencit Putih Betina. Skripsi Fakultas Farmasi Universitas Ahmad Dahlan. Jogjakarta

5. Turner R. 1965. Screening Methods in Pharmacology. Academic press. New York

6. Robinson T. 1991. Kandungan Organik Tumbuhan Tinggi. Edisi keenam terjemahan Kosasih Padmawinata. ITB. Bandung
7. Anonim. 2004. Constitues and Ethnobotanical Database. $\quad$ http://www.ars-grin.gov/cgibin/duke/farmacy-scroll3.pl, 20 Juli 2004 